\title{
Traffic Demand Forecasting on Campus-Taking the West Campus of Shandong University of Technology as an Example
}

\author{
Xiaofeng Zheng \\ School of Traffic and Transportation, Beijing Jiaotong University, Beijing 100044, China \\ 17120953@bjtu.edu.cn
}

Keywords: traffic demand, school traffic, Investigation of traffic situation.

Abstract: Through the investigation and analysis of the traffic situation in the West Campus of Shandong University of Technology, this paper forecasts the traffic demand for the next year, and provides a basis for the future campus planning of the West Campus.

\section{Introduction}

With the rapid development of Chinese universities' planning and construction, University campus and its traffic planning and design has become a major concern of the community. At present, the campus traffic of various colleges in our country generally exists the mixed traffic situation of the slow traffic and the people-car altogether, which often causes the chaos of the campus traffic. The problems in road system, parking planning, public transport planning, traffic safety facilities and traffic organization in campus have brought unfavorable effects on campus traffic. Traffic survey is an ordinary, heavy workload and very important basic work. In order to solve the problems in the campus traffic planning and design, we must actively carry out systematic and planned traffic investigation work. Through the investigation, providing the accurate data information for the campus transportation planning design each aspect service.

\section{Investigation and analysis of traffic situation}

\subsection{Shandong University of Technology of West Campus overview}

Shandong University of Technology Campus covers an area of about 3600 acres, of which the West Campus covers an area of about 3000 acres. West Campus is located on the west side of Zhangdian District government, east of Nanjing Road, north of the Renmin West Road, south of the Xincun West Road, west of Beijing Road, 5.6 kilometers from the Zibo railway station, 2.7 kilometers from the passenger center. And West Campus is the main campus of Shandong University of Technology. Around the stone Crystal City, Kerry Garden, Zibo Sports Center, Zibo Experimental Middle school and other large population flow, high density of the region. Therefore, the network traffic pressure of roads which around Shandong University of Technology campus will be larger, resulting in the surrounding roads often congestion and other phenomena. The overall use of the land is shown in Figure 1. 


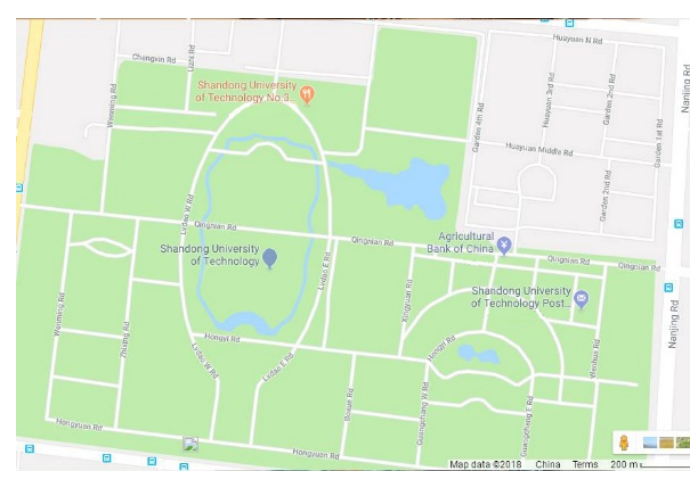

Fig. 1 The present situation of West campus

\subsection{Investigation and analysis on the present situation of campus roads}

The grade of road and the width of different grades of road are two important indexes to weigh the advantages and disadvantages of the campus road system, which is different from the factors such as campus size, campus location and school nature. The campus road grade divides the campus road function localization as the foundation, the complete campus road is composed of the following four levels: The Campus class road, the function partition grade road, the group class road, the House Road.

Through the investigation of some important roads in the West campus of Shandong University of Technology, the data obtained are as shown in table 1 according to the standard of school road grade.

Table 1. Road grading and width in West campus

\begin{tabular}{|c|c|c|c|c|c|c|}
\hline Number & Road name & Road level & $\begin{array}{l}\text { Road width } \\
\text { (m) }\end{array}$ & $\begin{array}{l}\text { Number of } \\
\text { motor road }\end{array}$ & $\begin{array}{l}\text { Width of the } \\
\text { motor road } \\
\text { (m) }\end{array}$ & $\begin{array}{l}\text { Sidewalk } \\
\text { width (m) }\end{array}$ \\
\hline 1 & Lvdao West Rd & the group class road & 14.4 & 2 & 4 & 3.2 \\
\hline 2 & Shiwuzhongxin North Rd & $\begin{array}{l}\text { the function } \\
\text { partition grade road }\end{array}$ & 18.8 & 2 & 6 & 3.4 \\
\hline 3 & $\begin{array}{l}\text { Qingnian Rd (Lvdao East Rd } \\
\text { intersection west section) }\end{array}$ & $\begin{array}{c}\text { The Campus class } \\
\text { road }\end{array}$ & 19.4 & 2 & 3.9 & 3.5 \\
\hline 4 & Boya Rd & $\begin{array}{c}\text { the function } \\
\text { partition grade road }\end{array}$ & 22.6 & 2 & 4.5 & 2.3 \\
\hline 5 & $\begin{array}{l}\text { Hongyi Rd (Tennis Court } \\
\text { Section) }\end{array}$ & the group class road & 15.6 & 2 & 4 & 3.9 \\
\hline 6 & $\begin{array}{l}\text { Wenming Rd (North } \\
\text { Section) }\end{array}$ & the group class road & 15.8 & 2 & 4.1 & 3.8 \\
\hline 7 & Xinyuan Rd & the group class road & 6 & 2 & 3 & 2.3 \\
\hline 8 & $\begin{array}{l}\text { Hongyi Rd (Information } \\
\text { Building Section) }\end{array}$ & the group class road & 12.2 & 2 & 3 & 4 \\
\hline 9 & Zhixing Rd & $\begin{array}{l}\text { the function } \\
\text { partition grade road }\end{array}$ & 6.2 & 2 & 3.1 & 0 \\
\hline 10 & Lvdao East Rd & the group class road & 14.2 & 2 & 4 & 3.1 \\
\hline 11 & Hubin Rd & $\begin{array}{l}\text { the function } \\
\text { partition grade road }\end{array}$ & 17.6 & 2 & 6 & 2.8 \\
\hline 12 & Chengxin Rd & the group class road & 6 & 1 & 6 & 0 \\
\hline
\end{tabular}

According to the table above, many roads belong to the cluster-level roads and functional zoning roads, but there is no restriction on the travel of motor vehicles.

The use of various grades of road is not clear, all roads for motor vehicles, non-motorized vehic 
mpus, to limit the traffic of motor vehicles on campus, in order to reduce the conflict between motor vehicle, non-motorized vehicle and pedestrian.

Survey on the traffic flow of the main sections of the West Campus Peak period, that is, from Monday to Friday morning 7:30-8:05 and noon 11:45-12:20 period, as shown in table 2.

Table 2. Traffic volume of main road during peak period of West Campus

\begin{tabular}{|c|c|c|c|c|c|c|}
\hline \multirow{2}{*}{ Road name } & \multicolumn{2}{|c|}{$\begin{array}{c}\text { Pedestrian traffic } \\
\text { volume(people/35min) }\end{array}$} & $\begin{array}{c}\text { Vehicles } \\
\text { non-motor traffic } \\
\text { volume(car/35min) }\end{array}$ & \multicolumn{2}{c|}{$\begin{array}{c}\text { Traffic volume of } \\
\text { motor(car/35min) }\end{array}$} \\
\cline { 2 - 7 } & $\begin{array}{c}\text { Early } \\
\text { Peak }\end{array}$ & $\begin{array}{c}\text { Midday } \\
\text { Peak }\end{array}$ & $\begin{array}{c}\text { Early } \\
\text { Peak }\end{array}$ & $\begin{array}{c}\text { Midday } \\
\text { Peak }\end{array}$ & $\begin{array}{c}\text { Early } \\
\text { Peak }\end{array}$ & $\begin{array}{c}\text { Midday } \\
\text { Peak }\end{array}$ \\
\hline Lvdao West Rd & 899 & 2085 & 464 & 1185 & 25 & 49 \\
\hline Shiwuzhongxin North Rd & 1608 & 815 & 686 & 573 & 44 & 40 \\
\hline $\begin{array}{c}\text { Qingnian Rd } \\
\text { (Lvdao East Rd intersection west } \\
\text { section) }\end{array}$ & 412 & 475 & 359 & 361 & 173 & 143 \\
\hline Boya Rd & 66 & 194 & 116 & 237 & 137 & 72 \\
\hline Hongyi Rd (Tennis Court Section) & 2033 & 1430 & 470 & 266 & 35 & 38 \\
\hline Wenming Rd (North Section) & 168 & 797 & 359 & 512 & 35 & 32 \\
\hline Xinyuan Rd & 410 & 503 & 233 & 176 & 27 & 26 \\
\hline Hongyi Rd (Information Building & 679 & 836 & 235 & 217 & 42 & 31 \\
\hline Section) & 147 & 194 & 212 & 202 & 20 & 18 \\
\hline Zhixing Rd & 1829 & 1776 & 540 & 699 & 10 & 13 \\
\hline Lvdao East Rd & 114 & 204 & 184 & 232 & 73 & 54 \\
\hline Hubin Rd & 116 & 372 & 149 & 195 & 0 & 0 \\
\hline
\end{tabular}

According to the data of the survey, the vast majority of traffic flows were undertaken during the peak hours of Lvdao East Road, Lvdao West Road, Shiwuzhongxin North Road and Hong Yi Road.

Lvdao East Road is located on the west side of the second stadium, which mainly undertakes the traffic between the 5-22 dormitory building and the 3rd teaching building and the library. The road width of $14.2 \mathrm{~m}$, sidewalks wide $3.1 \mathrm{~m}$. Although the heavy traffic flow, but the breadth of the road is wide, basically can meet the demand.

Lvdao West Road is located on the eastern side of 12, 13th teaching building, which mainly undertakes the traffic between the northern living area and 12, 13th teaching building and the traffic between the library. Its width of $14.4 \mathrm{~m}$, sidewalks wide $3.2 \mathrm{~m}$. During peak hours, the pedestrian flow in Lvdao West Road is beyond the reach of its sidewalk.

Shiwuzhongxin North Road, situated between the No. 8th Dormitory building and the 9th dormitory building, is mainly responsible for the traffic flow from the school to the North Outer Ring Road and to the dormitory building. Its width of $13.4 \mathrm{~m}$, sidewalks wide $3.4 \mathrm{~m}$. The phenomenon of the road machine is very serious, and the pedestrian is parked on both sides of the pavement, which leads to a serious shortage of pedestrian capacity.

Hong Yi Road is located between the 3rd teaching building and second stadium, which mainly undertakes the traffic volume between the north side living area and the 3rd teaching building. The width of the road is $15.6 \mathrm{~m}$, the sidewalk width is $3.9 \mathrm{~m}$. The pavement of the road is occupied by the non-motor vehicle, the pedestrian space is severely compressed, which leads to the mixed phenomenon of pedestrians, non-motorized vehicles and motor vehicles in this road. 


\section{Using Transcad for OD back-pushing}

Create the following road network layer and zoning layer, add the following attributes to the road network layer. And enter the flow rate of each section in advance, calculate the capacity of the traffic and the travel time of each section, the data is shown in table 3:

Table 3. Flow rate, traffic capacity and travel time of each section

\begin{tabular}{|c|c|c|c|c|}
\hline ID & Length & Name & Peak traffic & Traffic capacity \\
\hline 1 & 75.57 & $\begin{array}{c}\text { Qingnian Rd (Lvdao East } \\
\text { Rd intersection west } \\
\text { section) }\end{array}$ & 986 & 1800 \\
\hline 2 & 58.54 & Xinyuan Rd & 708 & 1800 \\
\hline 3 & 61.10 & Guangchang West Rd & 588 & 1800 \\
\hline 4 & 76.95 & Hongyi Rd & 2888 & 1800 \\
\hline 5 & 101.06 & Zhixing Rd & 449 & 1800 \\
\hline 6 & 181.84 & Lvdao West Rd & 1633 & 1800 \\
\hline 7 & 70.46 & Boya Rd & 257 & 1800 \\
\hline 8 & 64.43 & $\begin{array}{c}\text { Hongyi Rd (Information } \\
\text { Building section) }\end{array}$ & 4000 & 1800 \\
\hline 9 & 250.36 & Wenming Rd & 617 & 1800 \\
\hline 10 & 78.80 & Shiwuzhongxin North Rd & 2714 & 1800 \\
\hline 11 & 196.95 & 3rd Canteen East Rd & 2564 & 1800 \\
\hline 12 & 53.60 & Lvdao East Rd & 2878 & 1800 \\
\hline 13 & 147.95 & $\begin{array}{c}\text { Southeast Corner of 5th } \\
\text { Dormitory Building }\end{array}$ & 443 & \\
\hline
\end{tabular}
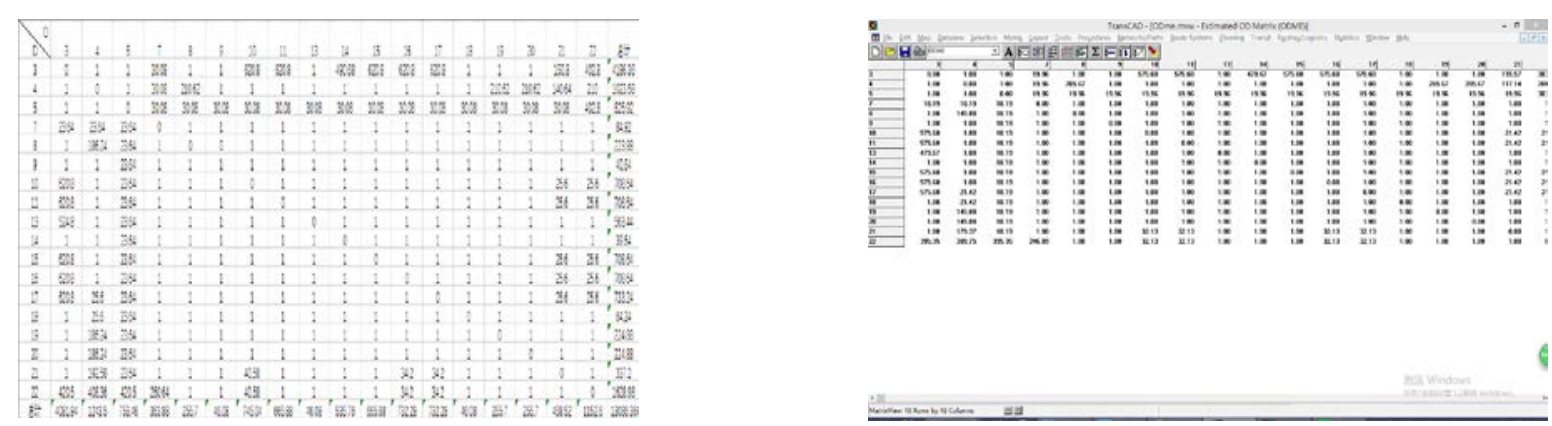

Fig. 2. Traffic community division Fig. 3. OD traffic between the various traffic communities

Using TransCAD to carry out OD back-pushing, the traffic plot as shown in Figure 2 and the OD traffic between each traffic area shown in Figure 3 are obtained.

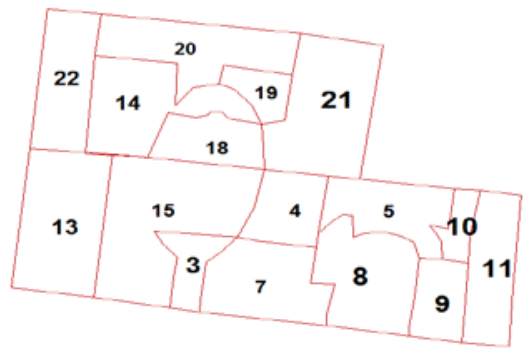

Fig. 4. Forecast of traffic volume of West Campus in future years 
Based on the current OD table, we use TransCAD to forecast the traffic demand of West Campus for the next year, the results are as shown in Figure 4.

\section{Conclusion}

This paper investigates the road situation of the West campus of Shandong University of technology and analyzes the problems of the West campus in this aspect. According to the survey, to make traffic demand forecasts forecasts of the West campus. To lay a good foundation for the future campus planning, design and management. And on this basis, take appropriate improvement measures to create a safe, green and quiet campus traffic environment.

\section{References}

[1] Fitzpatrick, K.et al., Guidelines for Planning, Designing, and Operating Bus-Related Street Improvements. Texas: Texas Transportation Institute, College Station, 1990.

[2] Transportation Research Board National Research Council. Impacts of Access Management Techniques[R]. National Cooperative Highway Research Program, 1999.

[3] Hensher DA, King J. Parking demand and responsiveness to supply, Pricing and location in the Sydney central business district [J]. Transportation Research, 2001, 35A (3):117-196. 